\title{
Class Struggle in Alice Munro's Selected Short Stories
}

\author{
Abu Fanani, SS., MPd Prof. Budi Darma., MA., PhD Prof. Dr. Fabiola D. Kurnia, MPd \\ Universitas Negeri Surabaya / State University of Surabaya, Indonesia
}

\begin{abstract}
In this article, I analyze Class Struggle in Alice Munro's selected short stories using Marxism as the main theory and Sociological theory of conflict as the supporting theory. Whilst, the method is qualitative content analysis in that I interpret and explain attitudes, behavior, and words of the characters in the texts through the theory of Marxism as the main theory and sociological theory of conflict as the supporting one. The result of this study is that the characters undergo class struggle caused by factors of their struggle. Change after the class struggle is visible, instead.
\end{abstract}

Keywords: class struggle, conflict.

DOI: $10.7176 / J L L L / 70-06$

Publication date:July $31^{\text {st }} 2020$

\section{Introduction}

Class struggle can happen because of the relationship between the capitalists and the wage laborers, the relationship which gives more advantages to one class but gives more disadvantages to the other class. Marx has expressed his idea that class struggle can happen at national level if one class enrich themselves at the cost of another class through the exploitation and oppression (Lasurdo, 2016:12).

Further, capital produces not only commodities or surplus value but also the capital relation itself: the capitalists and the wage laborers. The latter is the one who socially depends on the capital. Because capital continually produces new requirements for unfamiliar supplies and re-orders the hierarchy of requirements of workers, capital then produces workers with the requirement to possess and the requirement for money. This product of new requirements is exactly this side of the relation of capital and labor which is a contradictory product leading to class struggle (Lebowitz, 2003:179-180).

Besides, capitalism bears workers whose inclinations are fixed, who receive an early distribution of wealth, whose fate under capitalism is closed, and who have nothing to do to change their ration under capitalism. What they only can do is to make the most of their income under the early circulation of wealth and come to the maximum salary well-matched with their early wealth, which is, from being poor to being poor. However, redistributing wealth is their only way to improve their material conditions though such redistributing wealth is quite impossible to do under capitalism; wealth is the accumulation of income, whilst, income is given by early wealth, and there is no other way of the redistribution of wealth survives. Therefore, labors can merely tum to socialism, revolution is the only way they can do to make their material conditions a progress (Przeworski, 2002:230).

Then, class struggle refers to a struggle between the owners of the capital and the workers which is indicated by the surplus product and the control over its withdrawal. The surplus itself is defined as that part of the social product which is taken by the exploiters or the owners of the capital. Class struggle can mean a category defined by the exploitation by one social group of the productive activity of another. The surplus product or the exploiters and the workers who produce determine the general conditions in which the struggle develops between the exploiters and the exploited. Indeed, the struggle of those exploited by capitalism provokes both the control of production narrowly considered and the whole logic of the controlling society. The social relation caused by the owners of the capital and the workers is called the mode of production (Fernandez, 1997: 14-15).

Besides, Marx states that class struggle and socialism has connection that the class existence is simply related to specificstages of history in the growth of production, that class struggle unavoidably leads to the proletariatrepression, and that this repression itself merely establishes the change to the elimination of the whole classes as well as to a society without classes (Fernandez, 1997:20) which seems that Karl Marx's ideas of class struggle above are concerned with level of economic relations whose majority is called proletariat (Draper, 2011:113). Adam Przeworski (2002:52-59) in his Capitalism and Social Democracy comes up with the meaning of proletariat as follows:

1. The physical wage-earners in industry, transport, and agriculture, and those who do not have means of production and must sell their labor power if they want to survive as well as the majority of farmers, small producers, and traders with the little property they have.

2. The unfortunate and depressed people who no longer have their land and sell themselves, forcibly, to a capitalist.

3. The people who labor day and night, in front of a machine, in noise and dirt, with little payment so that they have to do again the job the following day to survive.

4. The class of modern wage employees who, with no means of production of their own, are reduced to 
selling their labor power in order to live.

5. Employees who no longer have their means of production, therefore, they must sell their labor power. 6. The group of people no longer with the means of production, that must live from selling their labor power to the capital owners and be oppressed in the capitalist production process: secretaries and executives, nurses and corporate lawyers, teachers and policemen, computer operators and executive directors. 7. The oppressed people such as full bloods and half-bloods, blue-collar and white-collar, wage-earners and others who live like them, those who are shabby and those wearing the uniforms of the Prussian officialdom.

From the explanation of the class struggle above I come to the understanding that class struggle is the struggle between two classes in society: the capitalist and the proletariat which the former refers to those who are high in economy who can control the low ones. Whilst, the latter refers to those that sell their labor power/become the workers who work under the capitalist and the people in general: teachers, nurses, traders with small property, farmers, all of whom becomes my research in this article.

Many writers analyse social class and class struggle in their articles; Putra, et. al., (2014) in their article Class Struggle as the Impact of Oppression Seen in Clifford, study about class struggle by the oppressed proletariat against the oppressing capitalist, Kurnia, et. al. in their article Social Class and Class Struggle in Suzanne Collin's the Hunger Games, study about the struggle between the bourgeois represented by the Capitol and the proletariat represented by District 12, Farahmandian, et. al., (2013) in their article Angela'S Ashes: Class Struggle and the Dream of Betterment, study about the class struggle and its effects on the society and characters, Healy (2008) in his article Misreading Mao: On Class and Class Struggle, studies about the rejection of misinterpreting Mao's thought that has broken up with Marxism, Royanian, et., al., (2016) in their article Class Oppression and Commodification in Shakespeare's Hamlet and Merchant of Venice, study about analyzing Shakespeare's Hamlet and Merchant of Venice, Shankar (2016), in his article The Comparative and distinctive study of class and caste conflict in MulkrajAnand's 'Coolie' with Chinua Achebe's 'No longer at ease,' studies about class and caste conflict research with the forms of conflict direct violence like wars dispute to get assets as well as cheap worker, policemen beating poor blacks, as well as the labors endeavor to manage their workroom and economy, Pandey (2016) in his article Class-Culture Conflict in Kanyadaan: Pseudo-Vein of Revenge and Revolution, studies about the theme of marriage among a higher caste Brahmin girl and lower caste Dalit man, Sadek (2014) in his article the Struggle of African Women in Selected Works by NgugiWaThiongo studies about resistance mechanisms used by African women in a society dominated by male. Though most of the studies above use Marxism but there are differences in the finding from my study.My study, then, deals with the class struggle - though their oppression is because of the same economic problems as most of the above studies - concerning with lower economic people cornered and oppressed by the higher ones found in different literary worksFurther, the short stories I analyze are "Royal Beatings,"“the Beggar Maid,"and the "Hired Girl."

\section{Theoritical Background}

Further, as the characters doing class struggle are found in the literary works, therefore, I have to refer to two grand theories: Marxist literary theory bearing Marxism as the main theory and sociology of literature bearing sociological theory of conflict as the supporting theory. Both Marxist literary theory and Sociology of literature talk about people dealing with economy and social class within literary works. Within Marxism, there are social classes creating gaps within the society so that one of the classes is in conflict against the other and this conflict triggers them to be in struggle to get a better condition. Thus, sociological theory of conflict is appropriate to support Marxism to elaborate their conflict. The followings are little bits about Marxism and Sociological theory of conflict.

Karl Heinrich Marx and Frederic Engels come up with the idea of Marxism because of imperialism. Coming from the Latin term 'imperium' meaning 'command,' imperialism deals with dominating one area by another done by direct or indirect control; direct control refers to the conquest of one area by a governing class though it could not be a permanent conquest of a population. Further, imperialism becomes more general term which refers to a form of economic domination of one area by another. It seems that colonialism is then well-maintained as a factually special case of imperialism historically first seizing a form of colonialist. Nonetheless, imperialism often sustained the passing of colonialism in that it continued the removal of a leading class from the occupied area after the occupied area got its independence from colonial rule. Imperialism shares with colonialism certain assets of economic control of one geographical area over another, assets that get changed after decolonization. However, these assets are invariant both in colonial and post-colonial contexts (Patnaik, et. al., 2017: ix-x). Thus, it is understandable that imperialism not only dominates area/areas politically but also economically, therefore, there will be two social stratifications looked at from economic point of view: the dominator and the dominated people, the former has a great capital to build their economy/those with a lot of property/rich people, whilst, the latter are the majority people that sell their labor power to the capitalist/those with little property/poor people, due to which Marxism comes up. As a result of the stratification in society from economic point of view, the rich people, then, 
oppress the poor one. The rich people can oppress the poor one because a person who owns property can control the whole society (Dahrendorf, 1959:14). Since my dissertation deals with rich people oppressing poor one, therefore, Marxism is appropriate to apply. Thus, Marxism and culture have a close relation; human beings and culture are inseparable, whilst, in Marxism, human beings are mostly economically dominated people, therefore, they make their own culture based on economic stratification.

Sociological theory of conflict elaborates the conflicts between people because of economic stratification, a higher class oppressing the other one, for example, the rich against the poor whose influences of economy provoke mainly the change of society (Giddens et. al., 2017:13) and the conflicts that happen in Alice Munro's selected short stories are the conflicts in small domains.

\section{Analysis and Discussion}

Dahrendorf (1959:10-14), in Class and Class Conflict in Industrial Society, elaborates capitalist mode of production that forms classes in society consisting of wage laborers, capitalists, and landowners. The existence of the mentioned three big classes, further, can be noticed because of property which can influence the change of society. Besides, as the control of minority over the whole country through property, property then triggers conflicts of class. Thus, a person who owns property can control the whole society that is called the bourgeois owning the means of production.

Further, property that can change the whole society is found out in "Royal Beatings," and "the Beggar Maid," which is the higher class treatment towards the exploited classes that make them unbearable in the mentioned selected short stories.

In "Royal Beatings," I find out that the wage laborer class is undergone by Rose (though she is not really a wage laborer but the treatment from the other indicates such) who undergoes a bad treatment from her step-mother, Flo, who behaves as if she were a rich person (the capitalist class). I suggest Flo here represents the higher class one as her behavior to her step-daughter represents the employer/the exploiter to the worker/the exploited. Consequently, Rose is in conflict against her psychologically in the form of being unbearable towards her stepmother's exploitation. Even though Rose is only a step-daughter, she should confront her step-mother patiently, however, her being indignant arises. Thus, it is a kind of struggle that she cannot control her emotion and wishes to get free from her step-mother's unkind treatment.

At the first, or maybe the second, crack of pain, she draws back. She will not accept it. She runs around the room, she tries to get to the doors. She runs, she screams, she implores (Munro, 1978:20).

Rose cannot stand of facing her step-mother's treatment by her feeling the pain, drawing back, running around the room, screaming, imploring all of which show that she does a struggle, a struggle from a person who is exploited by a playing-rich step-mother. The step-mother regards Rose as somebody who has nothing (she should have everything because she has the right to inherit her father's property), yet, her step-mother, Flo, controls everything, even her body and soul. Flo's statement towards Rose," who do you think you are?" (Munro, 1978:17) indicates a question that is used to underestimate somebody else in a matter of economy which means that Flo regards herself as belonging to a higher social class than Rose, in this case, she is the owner of capital as Karl Marx states in A Guide to Marx's Capital Vols I-III, that class in society can be formed based on the capitalist mode of production one of which is the owner of capital (Smith, 2012:180). Besides, this question is a criticism of a social class that is not understandable by the US readers at that time expressed by the American Publisher, Knopf (May, 2013:129).

Besides, the quotation above gives me a vivid understanding that social class is found everywhere; it can be found in working place, at school, and even in the householdwhich I refer to Bronislaw Malinowski that states that every human being is born into a family, a religion, a system of knowledge, and often into a social stratification and political constitution, which, often having existed for ages beforehand, are not changed or even affected during his lifetime. Further, in the development of his/her behavior, every human regardless man or woman, young or old, healthy or sick, cannot get rid of the systems of organized activitiesinto which their culture can be divided; home and business, residence and hospital, club and school, political headquarters and church, everywhere we find a place, a group, a set of by-laws, and rules of technique, and also a charter and a function, all of which establish their culture (Malinowski, 1961:46-47, see also Da Cunha, 2009:03) and within a culture there is a class(Andreatta, et. al., 2013:36). Regarded as being a lower class, Rose cannot do nothing unless she refuses the treatment as well as cries out for the pain which indicates that the character is unbearable to live within the household any longer.

Rose's not being able to stand to be despised can be found again when she will get married to PatrickPatrick is from a family who owns capital/owns a department store that makes Patrick's parents capitalists-who underestimate her being from the poor family in "the Beggar Maid."

"Why am I supposed to love you? Why do you act as if there was something wrong with me if I didn't? You despise me. You despise my family and my background and you think you are doing me a great favor-" (Munro, 1978:76).

The quotation shows that Rose cannot stand being with her future husband, Patrick, a psychological conflict, 
since Patrick underestimates the social background Rose comes from. The difference in economic life of Patrick and Rose is so deep that Rose feels inferior to be with him. Thus, again, Rose shows the class struggle, herself with the lower class background (her parents run a small business) against Patrick, her future husband with the higher class background (capitalist one). Further, her expression 'why am I supposed to love you?' means that she can no longer defend her love to Patrick; the term 'suppose' means a must that must be done by somebody but because of something, that somebody avoids of the duty which indicates that he/she cannot stand doing that thing. 'Why do you act as if there was something wrong with me if I didn't?' the use of the verb 'was' instead of 'were' indicates that the character gets out from speaking the formal English which means to strengthen her being blamed by her husband.

Other form of psychological conflict is ignoring the exploiterthat is found out in "the Beggar Maid" and "Royal Beatings." As mentioned above that property can control the society, in this case, the society is a small society which is a future family. In a connection leading to a married life, differences brought by the future husband and the future wife should be able to overcome the problems and there should not be difference in class from which they come. However, it does not happen to Rose and Patrick, the former comes from the poor family, whilst, the latter, the rich one, still, this differences in social class cannot be united into one class in that connection, consequently, the lower class becomes the victim of the other. James Carscallen in The Other Country Patterns in the Writing of Alice Munro comments on Rose's fate living with Patrick, in "The Beggar Maid," a humble girl takes a risk on "unheard-of riches" (Carscallen, 1993:12). It means that Rose, the poor person, is not important in the eye of the riches, that is why, as the lower class person, she struggles against Patrick, the higher class one by ignoring Patrick as her future husband who behaves as the exploiter.

"Nothing!" Rose said, turning herself radiant and attentive once more. But she kept forgetting, the new developments interfered, and she had finally to give in to that struggle, more or less ignoring Patrick" (Munro, 1978:68).

Rose's behavior towards Patrick's treatment towards her still cannot make her stop struggling against him. She shows him another struggle which is ignoring Patrick as her future husband. On one hand, Rose should treat Patrick for the sake of the future marriage, on the other hand, Patrick should have treated Rose without considering the class background from which Rose comes. However, what Dahrendorfstates that the control of minority over the whole country through property which then triggers conflicts of class(1959:10-14) is undergone by Rose. Rose feels that she has been controlled by Patrick due to his parents' property by not only underestimating Rose's economical background but also underestimating Rose's accent, "Patrick loved her. What did he love? Not her accent, which he was trying hard to alter" (Munro, 1978:68) which make Rose ignore him. Here, a different social class is shown by Patrick through his hatred of Rose's accent," though such class can happen because of the use of language, (Williams, 1960:271) which is the cultural theory.

Further, Rose's economically poor background can be seen in the following quotation:

"We come from two different worlds," she said to him, on another occasion. She felt like a character in a play, saying that. "My people are poor people. You would think the place I lived in was a dump." (Munro, 1978:63)

It is clear that the problem faced by Rose and Patrick, the future husband and wife, is class problem; Rose from the lower class (low economical background), Patrick from the high class (high economical background). It turns out that instead of Rose's poorly economical condition, Rose's surrounding is a dump which is full of garbage, compared to Patrick, it is too distant "He came from British Columbia. His family was rich" (Munro, 1978:56).

Another psychological conflict, ignorance, Rose makes to Patrick is that Rose stops loving Patrick because Patrick has hated Rose, Rose's background as well as Rose's family.

"I never loved you. I never wanted to. It was a mistake."

"All right. All right. You made your point."

Patrick's face was so white the birthmark stood out like a cut, and that only made her eager to continue.

"Why am I supposed to love you? Why do you act as if there was something wrong with me if I didn't? You despise me. You despise my family and my background and you think you are doing me a great favor-" (Munro, 1978:76)

As mentioned above inculture is the way of life of a specific people living together in one place that can be seen,one of which, in their habits (Milner, 2003:27-28), accordingly, Rose has different habit from Patrick leading to different social class through which emerges a class struggle. Thus, the quotation above shows that Rose as a humble girl that has just been shown Patrick's property by his mother, feels that she is not worthy of Patrick so that she has to get rid of him by deciding not to marry him that earlier before she had been engaged to Patrick. In other words, she ignores Patrick with the following verification "I don't want to see you, ever!" she said viciously. But at the door she turned and said in anormal and regretful voice, "Good-bye" (Munro, 1978:77).

Another kind of the psychological conflict done by the characters is that the characters behave in a low profile way towards the higher class people, which can be found out in "the Beggar Maid" and the "Hired Girl." In "the Beggar Maid," Patrick is offered a house by his father to live with Rose for their next marriage. However, as Rose 
feels that she comes from economically poor family, she resists the offer. I strongly believe that Rose behaves in such a way that she refuses the house because she cannot live the way Patrick's parents live which is quite different from the way she lives with her parents that is appropriate to what Eliot states above that culture is the way of life of a specific people living together in one place that can be seen, one of which, in their habit (Milner, 2003:27). Rose's habit is quite different from Patrick's habit which Rose tries to drag Patrick into her habit in a matter of dwelling.

"'I don't want a house like that! I don't want to live like that!" "We'll live however you like. We'll have whatever kind of house you like." Provided it's not a dump, she thought nastily"” (Munro, 1978:73).

Besides, Rose's worry of living with Patrick in the offered house is not without a reason. Instead of Patrick, Patrick's sister seems to humiliate Rose's social background. In addition, a difference in economy will trigger a class struggle as Dahrendorf states that if the condition of economy of people is different from that of other people, they will make their own class as they oppose the other one for their separation in their way of life, their education, as well as their interests (Dahrendorf, 1959:14). What Rose does by opposing Patrick's father's offer is a sort of class struggle because the way of life and the interests between Rose and Patrick's family are quite different from each other.

What Dahrendorf states above can be seen in the "the Hired Girl" within Alice Munro's The View from Castle Rock. In "the Hired Girl," the first person I is presented to be a girl who has maids in her parents' house "We called our maids hired girls," I added. "That was what we called them, at home" (Munro, 2006:148) but for a temporary time, she has to be hired in Mrs. Montjoy's house. As a matter of fact, she is reluctant to be called a maid, accordingly, she is in psychological conflict against her condition in a low profile way.

"Anybody could see why. To put myself somewhere near her level. As if that was possible. As if anything

I had to say about myself or the house I came from could interest or impress her" (Munro, 2006:148).

The quotation above implies that the first person I feels that she is lower in economy than her employer, therefore, what she can do to struggle against such a condition is through a low profile way because 'to put myself somewhere near her levelas if that was possible' meaning that she wants to be like Mrs. Montjoy but she cannot. Besides, she is aware that what she has at home will not attract Mrs. Montjoy.

Thus, the characters behave in a low profile way because there are differences in economic conditions; in "the Beggar Maid," Rose refuses the offer because she has undergone a bad treatment from Patrick's sister as will be explained in the factors. In "the Hired Girl," the first person I feels humiliated, though she has hired girls at home, because she cannot catch up with her employer's level of economy so she behaves in a low profile way.

\section{Conclusion}

From the analysis above, I draw to a conclusion that the characters do class struggle are through psychological conflicts: their being unbearable to the rich people, ignoring the rich people, and behaving in a low profile way.

\section{Acknowledgement}

In this sub-chapter, I would like to express my gratitude. First of all, my gratitude goes to Prof. Budi Darma and Prof. Fabiola D. Kurnia who have guided me to finish my article. Second of all, my gratitude goes to Dr. Supriyatno, M. Si., M. Pd., who has encouraged me to finish this article and last of all, my gratitude goes to my wife and two daughters who have made me alive to finish this article.

\section{References}

Andreatta, Susan. 2013. Elements of Culture, An Applied Perspective. Wadsworth.

Carscallen, James. 1993. The Other Country Patterns in the Writing of Alice Munro. Cambridge University Press. Draper, Hal. 2011. Karl Marx's Theory of Revolution, Volume 3 The Dictatorship of the Proletariat. Aakar Books for South Asia.

Fernandez, Neil C. 1997. Capitalism and Class Struggle in the USSR, A Marxist Theory. Avebury.

Giddens, Anthony, et. al. 2017.Essentials of Sociology. W.W. Norton \& Company, Inc.

Lasurdo, Domenico. 2016. Class Struggle, A Political and Philosophical History. Palgrave Macmillan.

Lebowitz, Michael A. 2003. Beyond Capital Marx's Political Economy of the Working Class, Second Edition. Palgrave Macmillan.

May, Charles E. 2013. Critical Insights, Alice Munro. Salem Press, A Division of EBSCO publishing, Ipswich, Massachusetts.

Malinowski, Bronislaw. 1961. A Scientific Theory of Culture and Other Essays. A Galaxy Book. New York, Oxford University Press.

Milner, Andrew, et. all. 2003. Contemporary Cultural Theory, An Introduction. UCL Press, The Tower Building, 11 York Road, London SE1 7NX.

Munro, Alice. 2006. The View from Castle Rock. Vintage International.

Munro, Alice. 1978. Who Do You Think You Are? Penguin Canada. 
Patnaik, Utsa, et. al. 2017. A Theory of Imperialism. Columbia University Press, New York. Przeworski, Adam. 2002. Capitalism and Social Democracy. Cambridge University Press.

Smith, Kenneth. 2012. A Guide to Marx's Capital Vols I-III. Anthem Press.

Williams, Raymond. 1960. Culture and Society. Anchor Books.

http://irjms.in/sites/irjms/index.php/files/article/download/166/166

https://www.iiste.org/Journals/index.php/RHSS/article/view/8359/8556

https://e-journal.usd.ac.id/index.php/JOLL/article/view/379

http://www.worldscientificnews.com/wp-content/uploads/2016/01/WSN-50-2016-186-196.pdf

https://jurnalmahasiswa.unesa.ac.id/index.php/litera-cultura/article/view/10431/10167

http://www.rjelal.com/4.3.16/191-194\%20Dr.\%20B.D.\%20PANDEY.pdf

https://eujournal.org/index.php/esj/article/view/2718/2570

https://doi.org/10.1080/00472330802309419 